Copyright (C) 2021 by Cherkas Global University

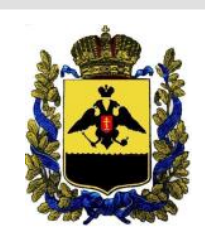

Published in the USA

Bylye Gody

Has been issued since 2006.

E-ISSN: 2310-0028

2021. 16(4): 1638-1649

DOI: $10.13187 /$ bg.2021.4.1638

Journal homepage:

https://bg.cherkasgu.press

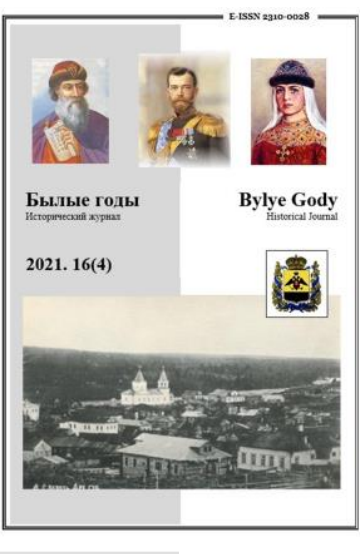

\title{
Liquidation of Bashkir's Contractual Lending in 1725-1733
}

\author{
Bulat A. Aznabaev a , *, Aleksey I. Kortunov b \\ a Bashkir State University, Russian Federation \\ b M. Akmullah Bashkir State Pedagogical University, Russian Federation
}

\begin{abstract}
In the literature, there are conflicting interpretations of the Russian citizenship of the Bashkirs of the XVI-XVIII centuries caused by the assertion that the Bashkirs did not have a political structure, which was understood exclusively as a form of chiefdom or state. At the same time, a number of researchers at the end of the XX century noted that the political unity of the people is not always achieved through the formation of rigid forms that alienate the sovereignty of the communities. Bashkir society of the middle of the XVI - first third of the XVIII century is an example of the creation of a military polity without the power vertical that is customary for nomads. In the middle of the XVI century the tribal formations of the Bashkirs united into a horizontal structure, which in Russian official documents of the XVIII century received the name "Bashkir Horde". The absence of an institutional elite in Bashkir society, represented by the Chingizids, who have the right to state power, determined the democratic character of the Bashkir polity. All decisions related to political existence (declaring war or concluding peace) were made at the yiyyn - "worldly gatherings" of Bashkir clans. The unification of the Bashkir clans into a single military structure was the result of an agreement with the Russian state, which obliged the Bashkirs to guard the southern border of their lands. In the south, the Bashkirs were opposed by nomadic chiefdoms and states (Kalmyks, Nogai, Kazakhs, Karakalpaks), then the Bashkirs were forced to create a single military structure, taking into account their specific social structure. The protection of its southern border is becoming a common concern of the entire Bashkir people, therefore, the most economically valuable territories located in the border zone have become the property of all Bashkir clans.

The main test of the military polity of the Bashkirs passed during the massive invasion of the Kalmyks in the 20 s and 30 s of the XVII century. If the former rulers of Bashkiria, the Nogai and Siberian Sheibanids, were forced to recognize the power of the Kalmyks, then the Bashkirs, even having lost the steppe estates behind the Yaik, not only managed to repel the onslaught of a numerically superior enemy, but went on the offensive. In the early 6os of the XVII century Kalmyk leaders conditioned the acceptance of Russian citizenship by the cessation of the raids of the Bashkirs and the return of prisoners. However, in the 20s of the XVIII century, the military organization of the Bashkirs faced the threat of disintegration for the first time. The southern clans, who lost their estates beyond Yaik as a result of the advance of the Kazakhs to the north, supported Russia's intention to build a city on the border of the Ufa province. However, the majority of the Bashkirs saw the intentions of I.K. Kirilov's desire of the state to take control of the southern border. The Bashkirs took this step by the authorities as an intention to terminate the citizenship agreement of the middle of the XVI century, which guaranteed the Bashkirs unprecedented privileges in the Russian state.

Keywords: Russian citizenship of the Bashkirs, the Bashkir Horde, the southern border of the Ufa district, the Orenburg expedition.
\end{abstract}

\footnotetext{
${ }^{*}$ Corresponding author

E-mail addresses: azbulattt@rambler.ru (B.A. Aznabaev), kortunov@rambler.ru (A.I. Kortunov) 


\section{1. Введение}

В настоящее время становятся особо актуальными вопросы истории российской государственности. Исходя из анализа этой проблемы, мы можем говорить о том, что она создавалась и развивалась, в том числе и на основе договора. Показательным историческим примером здесь может стать Башкирия, где договорные отношения играли важную роль. При этом стоит отметить, что развитие государственности на территории башкирских племен необходимо исследовать в контексте их отношений с Русским государством, которые, как показало время, складывались на договорной основе.

Эта проблема нашла свое отражение в отечественной и зарубежной научной литературе, где отмечается, что Башкирская орда, будучи негосударственной политией, сплотила башкирские родоплеменные структуры в военную организацию, предназначенную для защиты южных рубежей Башкирского края. Это военное образование возникает в середине XVI в. и прекращает свое существование в 1735 г. Ликвидация башкирской политии привела к изменению характера подданства башкир России. Исходя из этого, авторы определяют актуальность исследования, опираясь на ряд неопубликованных и опубликованных материалов.

\section{2. Материалы и методы исследования}

2.1. Основными источниками, на которые опирались авторы при подготовке исследования, являются неопубликованные документы, извлеченные из фондов: 119 (Калмыцкие дела (коллекция) фондов Посольского приказа и Посольской канцелярии), 248 (Сенат и его учреждения), 1324 (Материалы генерального и специального межевания Межевой канцелярии и местных межевых учреждений по Оренбургской губернии 1750-1910 гг.) Российского государственного архива древних актов (Москва, Российская Федерация) и фонда И-10 (Уфимское губернское по крестьянским делам присутствие) Национального архива Республики Башкортостан (Уфа, Российская Федерация). Также в исследовании использованы и опубликованные материалы (Материалы..., 1936; Материалы..., 1949; Материалы..., 2002; Документы..., 2012; Полное собрание..., 1830).

2.2. Методологическую основу исследования составили традиционные общенаучные принципы историзма и объективности. При проведении исследования авторы использовали такие методы, как хронологический и проблемно-исторический. Также методологической основой исследования является положение, согласно которому государство не является универсальной формой политической организации народа. Как отметили авторы работы «Альтернативные пути цивилизации», есть основания предполагать, что одинаковый уровень сложности социальнополитической (и культурной) системы, позволяющий решать равные по трудности задачи, встающие перед социумами, может достигаться не только в разнообразных формах, но и на различных эволюционных путях (Альтернативные пути..., 2000: 39).

\section{3. Обсуждение}

Характер российского подданства башкир в XVI-XVIII вв. в современной отечественной и зарубежной литературе не имеет однозначной оценки. Б.Э. Нольде, исследовавший процесс формирования имперских структур на национальных окраинах, считает, что башкиры не могли быть субъектом соглашения с Российским государством, поскольку у них отсутствовала какая-либо политическая организация (Нольде, 2013: 316). А. Каппелер отрицает не только договорный характер подданства башкир в середине XVI в., но и подвергает сомнению сам факт подвластности башкир России до середины XVIII в. (Каппелер, 2000: 31).

В советской историографии с 50-60-х гг. ХХ в. утвердилось мнение, что российское подданство башкир с середины XVI в. имело добровольный и даже договорный характер, но субъектом соглашения с российским государством выступала башкирская феодальная знать, а сами российскобашкирские отношения следует трактовать в дискурсе феодального вассалитета (Устюгов, 1947: 30-110; Демидова, 1956: 14-16).

В контексте клиентских отношений рассматривает российское подданство башкир и Мехмет Тепеюрт. В докторской диссертации «Башкирия между двумя мирами 1552-1824» он доказывает, что у России отсутствовала возможность установить прямое правление в далекой Башкирии. Это обстоятельство побудило российские власти признать автономию башкир. Автор категорически отрицает у башкир наличие какой-либо единой политической структуры. Общество раздиралось многочисленными межродовыми конфликтами, что препятствовало возможности установить разумные вассальные отношения. Россиянам пришлось иметь дело с таким количеством различных башкирских группировок, что единственно приемлемым решением для государства было оставить башкир в покое до тех пор, пока они не придумают какой-либо эффективный способ решения вопроса (Tepeyurt, 2011).

Чарльз Стейведел, как и Мехмет Тепеюрт, не отрицает договорный характер российского подданства башкир, но расходится с ним в оценке причин, побудивших башкирских лидеров добровольно признать власть русского царя. По мнению Тепеюрта, приобретение российского подданства было выгодно башкирской знати, которая таким образом укрепляла свою власть над рядовыми общинниками. 
Стейнведел доказывает, что башкиры стремились закрепить за собой земли, оставленные ногаями, и получить от России защиту от прежних властителей края (Steinwedel, 2016).

Утверждение, что башкиры получили от России военную защиту от ногаев и сибирских шибанидов, имеет давнюю историю (Рычков, 2002: 150). Если принять этот тезис, то следует согласиться с тем, что Российское государство не спешило выполнять свои обязательства. Военное присутствие русских в Башкирии, за исключением рейда казаков на Сарайчик в 1573 г. и двух походов в Башкирию стрелецких голов Турова и Волохова в 1585-1586 гг. (Корецкий, 1968: 65-71), было эпизодическим и незначительным. Но главным аргументом против концепции протектората является тот факт, что Уфимский уезд выпал из орбиты государственной защиты степной границы. В начале 70-х гг. XVI в., т.е. через 20 лет после принятия подданства башкирами, формируется всероссийская система по охране южных рубежей страны от нападений кочевников. Однако в нее не вошло левобережье Волги и южные границы Башкирии. Закамская черта, возведение которой началось в середине XVII в., прошла по западным рубежам Уфимского уезда, отделив Башкирию от центральных областей. Гарнизон Уфы до середины XVII в. состоял из 350 служилых людей, а ближайший русский город с более солидным служилым населением находился в 650 верстах. При этом площадь Уфимского уезда в XVII в. составляла 366,8 тыс. квадратных километров, т.е. равнялась современной территории Германии.

Отметим, что и сами ногаи к началу XVII в. уже не представляли серьезной угрозы для башкир. Последний ногайский наместник Башкирии - мурза Кара Кель-Мухаммед - в 1611 г. отказал России в военной помощи на том основании, что основные его силы стояли на заставах против калмыков и башкир (Трепавлов, 1997: 24). Тем не менее, большинство западных исследователей отрицает добровольный и договорный характер российского подданства башкир.

Однако, если соглашения башкир с Российским государством не было, как объяснить беспрецедентные привилегии башкир в XVII - первой половине XVIII вв.? Еще в XIX в. казанский профессор Н.А. Фирсов заметил, что ни один из народов, подвластных Романовым, не имел таких щедрых пожалований земельными владениями, никто не платил в казну так мало податей и налогов и никто не имел такой свободы в делах внутреннего самоуправления и религии, как башкиры (Фирсов, 1871: 297-401).

В литературе объяснение уникального положения башкир в Российском государстве выглядит неубедительно. Наиболее спорная трактовка принадлежит Б.Э. Нольде. Он считал, что Москва не видела здесь перспективы для себя, так как не ощущала никакой угрозы своим интересам, понимая, что Башкирия так или иначе будет освоена русскими. Поэтому, в отличие от Сибири, московское правительство препятствовало крестьянской колонизации Башкирии, опасаясь, что это может привести к конфликту с башкирами, - русские власти вообще старались никогда не ссориться с инородцами (Нольде, 2013: 287). Таким образом, Б.Э. Нольде полагал, что российская экспансия в Азии мотивировалась исключительно сопротивлением со стороны аборигенов.

М. Тепеюрт объясняет беспрецедентные права башкир неспособностью российских властей найти эффективный способ управления полукочевыми родами. А. Каппелер также отмечает ограниченность средств государства, не имеющего возможности установить прямое правление на юго-восточной окраине.

Необходимо констатировать, что основная причина противоречий в оценке характера подданства башкир заключается в игнорировании факта наличия у башкир политической организации. Следует отметить, что эта структура отнюдь не является научным концептом. В делопроизводственных источниках начала XVIII в. она официально именуется Башкирской ордой (РГАДА. Ф. 248. Оп. 3. Д. 107. Л. 201; РГАДА. Ф. 248. ОП. 15. Д. 821. Л. 351; РГАДА. Ф. 248. ОП. 13. Д. 75О. Л. 224; Добросмыслов, $1900:$ 28). Мы утверждаем, что российские власти имели дело не с враждующими между собой родоплеменными структурами, а со сплоченной политической организацией башкирского народа. Именно этим обусловлен договорный характер подданства, привилегии и сравнительно высокий уровень организованности башкирских восстаний XVII-XVIII вв.

Ошибочное отрицание у башкир политической структуры объясняется тем, что под политическим единством народа исследователи понимают исключительно институт государства. Вместе с тем К. Шмитт доказал, что понятие «политической организации» не может быть сведено к государству (Шмитт, 2016). Особенно в том случае, если речь идет о демократическом устройстве общества.

В конце XX в. исследователи негосударственных обществ обратили внимание на то, что, наряду с развитием жестких политических структур в форме государства, существует вариант в виде развития гибких межплеменных структур, не ущемляющих самостоятельность общин. При этом безгосударственные политии отнюдь не являются менее сложными в отношении структуры социума и уровня культуры, нежели стратифицированные государства (Альтернативные пути..., 2000: 35).

\section{4. Результаты}

Ч. Стейведел заметил, что сценарий принятия башкирами подданства России в середине XVI в. в терминологии и практике совпадает с процедурой установления власти Монгольской империи над 
башкирами. Действительно, сохранение власти родовой знати, согласие башкир платить ясак и участвовать в военных кампаниях Российского государства не вносили ничего нового в привычные отношения башкир с монгольскими ханами (Steinwedel, 2016: 119). Однако американский исследователь не учел того, что в середине XVI в. башкиры взяли на себя еще одно обязательство, которое не было заимствовано из практики подчинения башкир монголам. Требование царя защищать рубежи своей территории являлось историческим новшеством для башкир. В империи монголов башкирские земли занимали внутреннее положение. Вторжение в их пределы останавливали не войска, а законы империи, запрещавшие чингизидам включать земли башкир в свою улусную систему. Ситуация кардинально изменилась в конце 80-х гг. XV в., когда Башкирию оккупировали ногаи. Их правители игнорировали ясу, поскольку ногайская элита создала свою собственную легитимацию государственной власти. В период господства Ногайской орды маршруты башкирских кочевий регламентировались ногайскими биями, а имперский ясак собирал ногайский наместник Башкирии. Будучи самым мощным в военном отношении государством региона, Ногайская орда не нуждалась в военной службе башкир.

Положение башкир в Казанском ханстве было несколько иным. Здесь немногочисленные башкирские роды, находившиеся в зависимости от казанских ханов, несли военную службу в обмен на пожалование родовой знати тарханских ярлыков. Вместе с тем есть основания полагать, что башкирские тарханы Казанского ханства не участвовали в охране восточных границ Казанского ханства. Согласно исследованию В.В. Трепавлова, ногаи считались союзниками Казани и охранять границу с ними не было смысла. Летние кочевья ногайских мурз доходили до Казани (Трепавлов, 2001: 216). Башкирские тарханы были необходимы казанским ханам для войн со своим западным соседом. Не случайно пожалование ярлыков датируется временем обострения русско-казанских отношений. Башкирские тарханы в Казанском ханстве не имели своей политической организации. Их служба носила личный характер, они были инкорпорированы в татарское служилое сословие, о чем свидетельствует наличие у башкирских тарханов суюргалов на территории Казанского ханства (НА РБ. Ф. И-1О. ОП. 1. Д. 1328. Л. 263, 269об.).

Обязанность охранять юго-восточные рубежи государства принципиальным образом повлияла на политическое устройство башкирского общества. Все другие условия подданства башкир выплата ясака и участие в военных кампаниях России - относились к сфере, которая не выходила за рамки интересов отдельных родоплеменных структур. Так, субъектом землевладения в башкирском обществе являлся отдельный род. Глава рода выступал ответственным плательщиком ясака. Область местного самоуправления также ограничивалась родовыми судами. Даже в войнах, которые вела Россия, башкиры участвовали в составе своих родовых ополчений. В 1733 г. башкир Енейской волости Апас мулла доносил в Сенат: «...Велено было по указу отправить из всех четырех дорог 1000 человек и в то число и Казанской дороги мы, нижайшие, трижды 250 человек, а из нашей Енейской волости отправил я, нижайший, братьев своих всего 31 человек, дав им лошадей и деньги» (РГАДА. Ф. 248. Оп. 15. Д. 821. Л. 351).

Возложение на весь народ обязанности по охране границы не означало интеграцию башкирского ополчения в структуру вооруженных сил России. В деле организации пограничной службы башкиры не осуществляли координацию действий с российскими властями. Маршруты пограничных разъездов, места застав, характер участия в службе каждого родового подразделения определяли сами башкиры. Таким образом, российские власти не вмешивались в организацию пограничной службы на южной окраине Уфимского уезда. Башкирам лишь предписывалось предупреждать российские власти об угрозе нападения на внутренние области больших масс кочевников. В грамоте 1722 г., пожалованной всем башкирам после возобновления их российского подданства, указывалось: «...дабы они, видя е.и.в. милость, когда каракалпаки и киргис-кайсаки в российские городы возымеют намерение приходить для воровства, и они бы того предостерегали и приходить в российские пределы не допускали и в таких случаях свойски на них ходили и о том заблаговременно на Уфу и другие городы, куда надлежит, к воеводам ведомости подавали и в прочем во всем е.и.в. служили верно» (РГАДА. Ф. 248. Оп. 15. Д. 821. Л. 297).

Что представляла собой южная граница Уфимского уезда? В середине XVII в. она проходила от реки Самары по низовьям рек Большой и Малый Узень, далее по среднему течению Яика и по его притоку Илеку, верховьям Ори к верховьям Тобола (История..., 2011: 81). Фактически южная граница Уфимского уезда определяла территорию, с которой башкиры платили ясак. В дипломатической документации эти пограничные области так и назывались «государевых ясашных людей вотчинные земли» (РГАДА. Ф. 119. Оп. 2. 1630. Д. 1. Л. 4). Например, о том, что башкиры платили ясак и со своих вотчинных угодий на реке Эмбе свидетельствует документ Посольского приказа от 1649 г. (РГАДА. Ф. 119. Оп. 2. 1630. Д. 2. Л. 12). Однако уже к 1649 г. эти территории были захвачены калмыками. С этого времени граница России смещается более чем на 300 км северней до среднего течения реки Урал. Общая протяженность границы Уфимского уезда от реки Самара до реки Тобол составляла чуть менее полутора тысяч километров.

Обладали ли башкиры военным потенциалом, необходимым для обеспечения безопасности южной границы Уфимского уезда? До конца XVIII в. государство не располагало данными о

$$
-1641-
$$


численности башкир. Кунгурский бургомистр Юхнев, под видом купца побывавший в башкирских волостях в 1725-1726 гг., насчитал 11655 башкирских дворов. По его расчетам, каждый башкирский двор мог выставить трех мужчин, готовых воевать. Общее количество башкир обоего пола, по оценке Юхнева, составляло чуть менее 86 тыс. человек. Однако он не посчитал башкир некоторых волостей Сибирской дороги, которые не пропустили его в свои селения (Материалы..., 1949: 484). Таким образом, в 20-е гг. XVIII в. башкиры располагали войском в 40-42 тыс. человек. В.Н. Татищев, управлявший уральскими заводами и Оренбургской комиссией, писал, что до восстания 1735-1740 гг. башкир, только годных к войне, могло собраться до 6о тыс. (Татищев, 2005: 273).

Хорошее знание края и отработанная веками тактика ведения войны в горно-лесной местности позволяли башкирам не создавать непрерывной линии охраны границы. Караулы размещались на традиционных маршрутах преодоления кочевниками бродов. Так, в начале XVIII в. башкиры Казанской и Ногайской дорог Уфимской провинции доносили в Сенат: «...Мы, нижайшие башкирцы, стоим в своей стороне в четырех местах на карауле, чтоб от кайсацких и от каракалпакских набегов не пришло всяким обывателям и нам, нижайшим, разорения, а именно по рекам Самаре, Кинеле, а другой караул в вершинах Темескей реки, третий караул в вершине Ик реки, четвертый караул в вершине Садеф и Чермасан рек» (РГАДА. Ф. 248. Оп. 15. Д. 821. Л. 325). В случае появления конницы неприятеля у бродов башкиры, предварительно разделившись на две партии, не препятствовали началу переправы. Нападение начиналось в момент наибольшей уязвимости, когда половина войск неприятеля уже перешла брод, а другая только начинала преодолевать реку. К примеру, так был разгромлен калмыцкий отряд Чокула на реке Армынте в 1648 г. (РГАДА. Ф. 119. Оп. 2. Д. 1648. Л. 17-19). По-видимому, это очень древняя тактика, которую использовали башкиры. Секретарь миссии аббасидского халифа в Булгарию Ибн Фадлан в 922 г., описывая переправу через реку Чеган, отметил, что больше всего охрана посольства боялась нападения башкир. Сначала следовало переправить отряд бойцов, имеющих при себе оружие, прежде чем переправится что-либо из каравана. Они - авангард для людей, (следующих) за ними, (для защиты) от башкир, (на случай) чтобы они (т.е. башкиры) не захватили их, когда они будут переправляться (Путешествие..., 1939: 66).

Непосредственной организацией сторожевых пунктов занимались тарханы разных волостей. Они же первыми встречали противника. В 1733 г. Мулла Тохчура сообщал российским властям: «...От неприятельских набегов стоим на карауле, как тарханы, так и ясачные, служим денно и нощно с детьми своими, а ежели на городов и на селех и на деревни неприятельские люди набегать тотчас извещаем и ежели по нашей силе то их побиваем, а ежели не по нашей силе то оные неприятельские люди побивают» (РГАДА. Ф. 248. Оп. 15. Д. 821. Л. 297). В последнем случае башкирам приходилось встречать неприятеля уже на своей территории, что предполагало объединение ополчений отдельных родов в крупные военные отряды численностью от 500 до 3 тысяч человек. Необходимость в создании отрядов, превышающих это количество воинов, возникала только в ходе восстаний, когда башкирам приходилось иметь дело с хорошо организованными и вооруженными полевой артиллерией регулярными войсками русской армии. В 1733 г. башкиры в Уральских горах разгромили десятитысячный корпус хана Среднего жуза Семенеке, но на деле местному ополчению пришлось иметь дело с тремя отдельными группами казахских воинов, каждая из которых была уничтожена в разное время отрядами численностью 2-3 тысячи человек. Горно-лесной ландшафт исключал введение в сражение крупных масс конницы. Однако сбор даже тысячного отряда предполагал объединение ополчений нескольких родовых подразделений. Судя по расчетам бургомистра Юхнева, 60 волостей могли собрать 30000 воинов. На деле же даже небольшие отряды башкир, участвовавшие в отражении противника, состояли из башкир разных родов. В 1648 г., когда 150 калмыков напали на крестьян около Соловарного городка, их разгромил башкирский отряд из 560 воинов. После сражения тарханы 7 волостей подали челобитные, прося власти о денежной награде за полученные раны (РГАДА. Ф. 119. Оп. 2. 1648. Д. 1. Л. 13).

Участие всех башкир в защите южной границы Уфимского уезда обусловило появление феномена общебашкирского владения угодьями в приграничных территориях. Охотничьи угодья за Яиком и соляные месторождения на Яике считались собственностью всех башкирских родов. Для зимней охоты на тарпанов и сайгаков за Яиком, на Илеке, Уиле, Кииле и Оре в XVII-XVIII вв. составлялись партии башкир различных дорог и волостей. В 1648 г. на реке Уй были пленены 20 башкир, представлявших 7 волостей Сибирской, Казанской и Ногайской дорог, среди которых были и башкиры Гайнинской волости, родовые владения которой находились в 8оо километров от мест охоты (РГАДА. Ф. 119. ОП. 2. Д. 1648. Л. 156).

Владением всех башкирских родов считались соляные промыслы на Илеке. Судя по рапорту уфимского дворянина Матвея Аничкова 1718 г., башкиры не пропускали на Илек никого, кроме своих соплеменников. Они отказалась показать месторождения даже представителю администрации под тем предлогом, что «..они е.и.в. верные слуги и в такую землю, где неприятели всегда бывают и воюются не могут отвезти» (РГАДА. Ф. 248. ОП. 17. Д. 1131. Л. 544). Обычно за солью отправлялся отряд численностью не менее 3000 человек. Из этого числа только 300 человек загружали солью подводы. Основная же часть отряда занимала круговую оборону (РГАДА. Ф. 248. Оп. 17. Д. 1131. Л. 544). Сами участники подобных акций сообщали властям: «...От набегу воровских каракалпаков и 
киргиских кайсаков многие бывают побиты и в полон взяты и от лошадей лишены и за роспутием не дошед до домов своих от стужи позябают и от голоду помирают» (РГАДА. Ф. 248. Оп. 3. Д. 115. Л. 678).

Таким образом, в середине XVI в. родоплеменные структуры башкир столкнулись с необходимостью создания единой политической организации, поскольку только подобная сплоченная структура могла эффективно справляться с задачей охраны южной границы их территории и обеспечить всем башкирам доступ к природным ресурсам приграничных областей. Вместе с тем объединение башкирских родов в военно-политическую организацию не привело к появлению жестких надобщинных структур по типу вождества или раннего государства. При этом аналогичные вертикальные властные формы имелись у всех степных соседей башкир - казахов, калмыков, каракалпаков и ногаев.

Почему башкиры уклонились от традиционного для кочевых сообществ Северной Евразии пути создания политий по типу вождества или государства? Ответ следует искать в исторически сложившихся отношениях башкир с правителями монгольской империи. Башкирские земли Приуралья не вошли в улусную систему, получив от империи автономный статус, гарантировавший башкирским родам владение своими землями в обмен на выплату ясака и участие башкирского ополчения в военных акциях (Азнабаев, 2009: 154-161). В результате в башкирском обществе не сложилась институциональная элита (белая кость) в лице чингизидов, имеющих монопольное право на государственную власть. Поскольку в башкирском обществе не было сакрализированного лидера, родовые структуры не образовывали иерархическую вертикаль. Все родоплеменные структуры башкир независимо от численности населения и величины территории находились в отношении равенства по отношению друг к другу.

Тем не менее, отказ от государственного права монголов не помешал, к примеру, ногаям создать свое государство. В данном случае следует согласиться с объяснением А.В. Коротаева о том, что в определенных условиях (горные сообщества, островные или оазисные цивилизации) безгосударственные социумы способны более эффективно аккумулировать и расходовать ресурсы, чем централизованные государства (Коротаев, 2003: 64). В подобных обстоятельствах доля политического участия в контроле за ресурсами несравненно выше, нежели в традиционных государствах. К примеру, войска южных соседей башкир - калмыков, казахов и каракалпаков состояли из дружины правителя и племенного ополчения. Гвардии ханов и князей состояли из иноэтнических групп профессиональных воинов, лично зависимых от своих предводителей. Так, основу дружины хана Абулхаира составляли калмыки и башкиры. Именно ханские дружины играли роль войск быстрого реагирования. Племенное ополчение собиралось только с санкции родовых старейшин, и ханы не имели возможности быстро собрать большие массы войск (Бобров, 2015: 54-61).

У башкир при отсутствии ханских и княжеских дружин отряды родоплеменного ополчения постоянно находились в состоянии боевой готовности. О высоком уровне милитаризации башкирского народа, в частности, писал губернатор Казанской губернии Петр Апраксин: «Народ их проклятый, многочисленный и военный» (Материалы..., 1936: 257). Кунгурский бургомистр Юхнев в 1725 г. подтверждает эту характеристику: «Оной народ военной, по их маниру, почитай, в каждом дворе есть пансер, копье, лук и сабель, також де ружье, которое “турки” зовут» (Материалы..., 1949: 486). История столкновений башкир с калмыками, каракалпаками и казахами в XVII-XVIII Bв. показывает, что крупные сражения с привлечением более 1000 человек с обеих сторон имели место крайне редко. С калмыками за период с 1620 по 1661 гг. башкиры участвовали только в трех значительных столкновениях. С 1708 по 1735 гг. казахи и каракалпаки большими силами приходили в Уфимскую провинцию также три раза. Однако почти ежегодно имели место рейды небольших отрядов с целью угона скота и захвата пленных. И в этой малой войне башкиры не знали себе равных. В 1644 г. тайша Дайчин признавался послу Ивану Черникову-Онучину, что все нападения калмыков на башкир были неудачны, приводя к значительным потерям (История..., 2005: 364). В конечном счете тайши Дайчин и Мончак обусловили принятие российского подданства прекращением нападений башкир на калмыцкие кочевья.

Следует отметить, что военный потенциал калмыков многократно превосходил возможности башкирского ополчения. По оценке С.К. Богоявленского, численность войск калмыков в 20-е гг. XVII в. составляла 80 тысяч человек (Богоявленский, 1939: 87). После того как калмыкам в 40-е гг. XVII в. удалось подчинить себе ногаев и сибирских царевичей, объединенная мощь их войска значительно возросла. Тем не менее даже в начале 60-х гг. XVII в., в период наибольшего военного могущества калмыков, тайша Дайчин жаловался послу Ивану Горохову: «Злее всех башкирцы: всегда всякое зло калмыкам от башкирцев» (Соловьев, 1961: 224). Иоган Готлиб Георги, побывавший в южной Башкирии в начале 70-х гг. XVIII в., отмечал, что небольшой отряд башкир, в течение долго времени находясь в казахских степях, всегда одерживает победу над большим количеством казахов (Георги, 1799: 95).

Тем не менее не стоит преувеличивать возможности военной организации башкир. В открытой местности, допускавшей применение больших масс конницы, башкиры уступали калмыкам и казахам по причине их многократного численного преимущества. Так, к 60-м годам XVII в. башкиры утратили 
свои вотчинные угодья не только на Эмбе, но и в среднем течении Яика. В 20-е гг. XVIII в. казахи Младшего жуза вытеснили башкир со степных территорий по рекам Яик, Илек и Орь.

Отсутствие единого центра принятия решения также негативно влияло на эффективность действий башкирского ополчения. Политические решения, в том числе санкции на начало военных действий, принимались только на «мирских сходах», или, как их называли сами башкиры, «йыйынах». Официальная коммуникация уфимской администрации с башкирским народом осуществлялась на «собраниях башкирской орды» (РГАДА. Ф. 248. Оп. 15. Д. 821. Л. 452 ). Традиционно они проходили на седьмой четверг после пасхи в 16 верстах от Уфы на реке Чесноковке, отделявшей городскую округу от башкирских вотчинных земель. И.К. Кирилов писал, что у властей отсутствовала возможность обратиться к конкретным ответственным представителям, но приходилось адресоваться «ко всем башкирцам, чего взыскать ни на ком нельзя» (Материалы..., 2002: 100). Он писал, что вместо того, чтобы советоваться с властями о «мирских нуждах» или подавать челобитные, собравшиеся с утра начинали ругать воевод, приказных толмачей, называли их грабителями, ворами и разорителями. Только после щедрого угощения вином и мясом и вручения подарков (некоторые особо запальчивые критики воевод привозили домой до 50 рублей) башкиры писали похвальные письма, называя в них воевод добрыми и правдивыми (Материалы..., 2002: 101).

Отмеченные Кириловым отсутствие конструктивности и определенная ритуализированность чесноковских йыйынов обуславливались тем, что главные претензии башкир к российским властям выходили за рамки полномочий уфимских администраторов. В первой трети XVIII в. башкир возмущали захваты их земель яицкими казаками и крестьянами сибирских слобод. Башкиры были недовольны отказом правительства вернуть им вотчинные угодья, изъятые по указу Ингерманландской канцелярии в период петровских реформ, и остановить поток незаконных мигрантов из других уездов. Эти вопросы решались только в столице. Для таких случаев практикой управления башкир предусматривались отправки в столицу башкирских посольств. Как выяснила Н.Ф. Демидова, в XVII в. периодически башкирские делегации прибывали в Москву для урегулирования спорных ситуаций, не предусмотренных соглашением середины XVI в. о добровольном подданстве (Демидова, 2003: 180).

Следует отметить, что право контролировать южную границу государства предоставляло башкирам статус субъекта в международных делах. На протяжении XVII - первой трети XVIII вв. башкиры договаривались с калмыками, отправляли послов в Крым и Турцию, приглашали чингизидов из казахских степей.

А. Каппелер, отрицающий договорный характер башкирского подданства, отмечает, что до 1730-х гг. башкиры не подчинялись российским властям (Каппелер, 2000: 37). Однако отсутствие прямой власти государства над народом еще не означает полного суверенитета последнего. Американский историк и социолог Ч. Тилли заметил, что любая империя характеризуется тем, что центр связан с периферией непрямым способом (Tilly, 1997: 1-11). Обычно имперская полития предполагает наличие договора между центром и местной властью или осуществление власти центра через посредника, пользующегося значительной автономией в обмен на выплату дани и военное сотрудничество.

Интересно, что понятие «непрямое управление» Тилли дословно совпадает с терминологией официальной документации начала XVIII в. Казанский губернатор Петр Апраксин в 1712 г. призывал правительство привести башкир «в прямое подданство и учинить данниками прямыми» (Материалы..., 1936: 277). Следовательно, расторжение договорных отношений между Россией и башкирами в середине 30-х гг. XVIII в. означало ликвидацию почти двухсотлетней практики имперского управления регионом. С этого времени договорный характер российского подданства становится привилегией южных соседей башкир - казахов Младшего жуза.

Утрата башкирами контроля за южной границей своих земель началась до организации Оренбургской экспедиции. В ходе приема башкирских представителей в Санкт-Петербурге в 1733 г. был заявлен протест против возведения яицким казаком Василием Араповым крепости на устье реки Сакмары. Башкиры доказывали, что устье Сакмары является общей вотчиной семи башкирских волостей. Действительно, в российских актах данная территория была закреплена за семью волостями еще в 1628 г., т.е. после вторжения калмыков (РГАДА. Ф. 1324. Оп. 1. Д. 2247. Л. 122). Челобитчики в 1733 г. указали на то, что новая крепость препятствует охране границы и лишает всех башкир доступа к илецким месторождениям (РГАДА. Ф. 248. Оп. 15. Д. 821. Л. 412-415). Однако центр илецких промыслов находился южнее на 114 километров. Дело в том, что через устье Сакмары проходила единственная дорога на Илек и в казахские степи. В оберегательной грамоте 1628 г. отмечен «тележный путь на реку Узык». Как отмечено в уфимских станичных книгах 1643 г., именно до устья реки Сакмары доходили разъезды башкирских тарханов (Документы..., 2012: 47). Но не только за солью ездили башкиры через Сакмарское устье. Здесь находился так называемый Царев брод, который традиционно использовали калмыки, казахи и каракалпаки для нападений на российские владения. Несмотря на наличие актов, подтверждающих права башкир на устье Сакмары, Военная коллегия поддержала инициативу атамана Арапова. Более того, российские власти узаконили казачий форпост на Сакмаре и даже прислали крепостную артиллерию (Дорофеев, 1994: 
8-10). В указе Военной коллегии отмечено: «Построить крепость для оберегания границы на заставах по Яику, выше Яицкого городка, на устье реки Сакмары, близ башкирцев, где переправляются, ходят в Россию неприятельские каракалпаки и киргис-кайсаки» (Буканова, 1997: 42). И.К. Кирилов считал Сакмарскую крепость ключевым пунктом для обуздания башкир: «Сакмарск в таком удобном месте стоит, что на самом горле башкирском» (Материалы..., 2002: 104).

Потеряв важнейшую позицию в приграничном регионе, башкиры были готовы к дальнейшему наступлению России на их права контролировать южную границу Уфимской провинции. В 1733 г., когда проект И.К. Кирилова об основании города на реке Орь еще не был окончательно утвержден Анной Иоанновной, участник посольства Токчура Алмяков в своем зашифрованном письме, адресованном всем башкирам («на общее лицо»), призвал готовиться к восстанию. По всей Башкирии прошли йыйыны (Материалы..., 2002: 365).

При этом проект Оренбургской экспедиции не предусматривал отторжения собственно башкирских земель. И.К. Кирилов подчеркивал, что место будущего города должно находиться на границе башкирских и казахских земель. По его словам, хан Абулхаир хотел, чтобы город был построен «на меже» (Буканова, 1997: 94). Однако уже в начале 20-х гг. XVIII в. граница башкирских земель вновь сместилась к северу. В 1725 г. после джунгарского нашествия «немалое собрание» казахов Младшей орды подходит к рекам Орь, Илек, Уй и Тобол, выдавив башкир со своих охотничьих угодий (Таймасов, 2009: 49). Башкиры, чьи владения были захвачены казахами, поддержали план строительства города, надеясь с помощью российского присутствия вернуть вотчинные угодья. Этот факт был замечен и самым Кириловым. В своем проекте он указал, что на Эмбе и Яике казахи Младшей орды немало башкирской земли захватили (Полное собрание..., 1830: 309). Хан Абулхаир, по утверждению Кирилова, признал, что «..та земля башкирская и владелец здесь, которой сам того желает» (Буканова, 1997: 97).

В 20-х - начале 30-х гг. XVIII в. Башкирская орда, призванная защищать южные рубежи башкирских земель, не смогла противостоять захвату вотчинных угодий по Илеку, Яику, Ори и Тоболу. В период казахского натиска мы уже не видим былой солидарности родоплеменных структур. В конце августа 1733 г. один из самых влиятельных казахов Младшего жуза Букенбай предупредил зауральских башкир о готовящемся нападении на них десятитысячного корпуса Средней орды во главе с ханом Шемякой. Лидеру зауральских каратабынцев Таймасу Шаимову пришлось положиться только на сородичей, а также своих соседей - башкир Куваканской, Кущинской и Катайской волостей. В итоге казахи были разгромлены, но и башкиры понесли существенные потери (РГАДА. Ф. 248. Оп. 17. Д. 1191. Л. 57-61). В этой ситуации лидеры башкирских родов, испытавших наибольший ущерб от казахов, оказали помощь в военном утверждении России на своей южной границе. Именно Таймас Шаимов предоставил И.К. Кирилову свои вотчинные угодья для заведения хлебной пристани в верховьях Яика (РГАДА. Ф. 248. Оп. 22. Кн. 1524. Л. 1-4). Без этой перевалочной базы Оренбург лишился бы поставки продовольствия из сибирских уездов.

В 1732 г. в другом стратегическом пункте Уфимской провинции, на территории Табынских соляных промыслов, тархан Алдар Исекеев передает промышленнику Утятникову часть своей вотчины. В 1735 г. на этих землях была заложена Табынская пристань, сыгравшая важную роль в снабжении новых крепостей провиантом. Один из руководителей восстания 1735-1740 гг. Кильмяк Нурушев заявил на допросе, что именно этот поступок Алдара стал причиной башкирского бунта (Материалы..., 2002: 365). В 1725 г. И.К. Кирилов прямо указал на связь между лояльностью отдельных башкир и местоположением их вотчинных угодий: «Многие башкирцы служат и рачат, чтоб быть Оренбургу, да еще те самые, чья земля по Орь реке, а другие воры, у которых никакого владения здесь нет, открылись в нападении на идущия роты» (Добросмыслов, 1900: 24). Произошедший раскол башкирского общества на «верных» и «воровских» был настолько кардинальным, что на заключительном этапе башкирского восстания 1735-1740-х гг. карательные акции проводились в основном силами лояльных башкир.

\section{5. Заключение}

После строительства Оренбурга и почти трех десятков крепостей башкиры полностью утрачивают контроль за южной границей Уфимской провинции. В итоге происходит трансформация всей системы отношений башкир с русским государством. C 30-х гг. XVIII в. башкиры уже не предстают перед государством в форме военной структуры. Прежнее единство распадается, возникает широкий слой так называемых верных башкир, готовых к вооруженному усмирению своих единоплеменников. Эти социальные и политические процессы обусловили и институциональные перемены в отношениях с российским государством. В 1736 г. власти запрещают родовые йыйыны, которые являлись центрами принятия политических решений в башкирском обществе. Принципиально меняются характер и цели башкирских посольств, прибывающих в столицу после 1733 г. Участники этих миссий уже не избираются на йыйынах, а назначаются местными властями из числа новых лояльных старшин. Прием башкирских делегаций утрачивает переговорный формат, превращаясь в ритуальную демонстрацию лояльности монархии. Когда в 1742 г. на коронацию Елизаветы Петровны была направлена делегация башкир, то в ее состав входили только 
«доброжелательные» старшины, отобранные председателем Башкирской комиссии Л.Я. Соймоновым. В ходе башкирских посольств XVII - первой трети XVIII вв. представители подавали челобитные о «мирских нуждах», но делегация 1742 г. ограничилась монаршей аудиенцией, участием в коронации и получением подарков. В 1745 г. уфимский вице-губернатор П.Д. Аксаков так характеризовал поездку в столицу старшин: «..были в Москве... якобы от народу и, оболгав, испросили себе грамоту и получили награждение» (Рахимов, 2001: 34-43).

История возникновения и распада политии башкир (Башкирской орды) являет собой конкретно-исторический пример государственно-правового принципа, описанного Карлом Шмиттом: «Если некий народ страшится трудов и опасностей политической экзистенции, то найдется именно некий иной народ, который примет на себя эти труды, взяв на себя его защиту против внешних врагов» и тем самым политическое господство (Шмитт, 2016: 328-329).

\section{6. Благодарности}

Работа выполнена при финансовой поддержке Российского фонда фундаментальных исследований (грант №20-09-42053: «Трансформация отношений центра и этнической окраины в период Петровских преобразований (на примере нерусского населения Уфимской провинции первой четверти XVIII в.)».

\section{Литература}

Азнабаев, 2019 - Азнабаев Б.А. Апология племенной знати в «Дефтер-и-Чингизнаме» / Материалы Международной научной конференции «Политическая и социально-экономическая история Золотой Орды (XIII-XV вв.)». Казань: Изд-во Фэн АН РТ, 2009. Вып. 1. С. 154-161.

Альтернативные пути..., 2000 - Альтернативные пути к цивилизации. М.: Логос, 2000. 368 с.

Бобров, 2015 - Бобров Л.А. Военная организация казахских кочевников от Абулхаира до Кенесары (XVIII - первая половина XIX вв.) // Средневековые тюрко-татарские государства. 2015. № 7. C. 54-61.

Богоявленский, 1939 - Богоявленский С.К. Материалы по истории калмыков в первой половине XVII в. // Исторические записки. М.-Л.: Изд-во АН СССР, 1939. Т. 5. С. 48-101.

Буканова, 1997 - Буканова Р.Г. Города-крепости юго-востока России в XVIII в. История становления городов на территории Башкирии. Уфа: Китап, 1997. 253 с.

Георги, 1799 - Георги И.Г. Описание всех обитающих в Российском государстве народов. СПб.:

Типография Императорской Академии наук, 1799. Ч. 2. 634 с.

Демидова, 2003 - Демидова Н.Ф. Башкирские посольства в Москву в XVII в. // От древней Руси к России Нового времени. М.: Наука, 2003. С. 179-187.

Добросмыслов, 1900 - Добросмыслов А.И. Башкирский бунт в 1735, 1736 и 1737 гг. // Труды Оренбургской ученой архивной комиссии. Оренбург: Типо-литография Ф.Б. Сачкова, 1900. Вып. XVIII. 104 c.

Документы..., 2012 - Документы и материалы по истории башкирского народа (1574-1798).

Уфа: Гилем, 2012. $561 \mathrm{c.}$

Дорофеев, 1994 - Дорофеев В.В. Сакмарский городок // Оренбургский край. Оренбург: Оренбург. кн. изд-во, 1994. Вып. 2. С. 8-10.

История..., 2011 - История башкирского народа. Уфа: Гилем, 2011. Т. 3. 476 с.

История..., 2005 - История Казахстана в русских источниках. Алматы: Дайк-Пресс, 2005. Т. 1. $721 \mathrm{c.}$.

Каппелер, 2000 - Каппелер A. Россия - многонациональная империя: Возникновение.

История. Распад. М.: Традиция, 2000. 344 с.

Корецкий, 1986 - Корецкий В.И. Летописец с новым известием о восстании Болотникова // История СССР. 1968. № 4. С. 62-77.

Коротаев, 2003 - Коротаев А.В. Социальная эволюция: факторы, закономерности, тенденции.

М.: Восточная литература, 2003. $278 \mathrm{c.}$

Материалы..., 1936 - Материалы по истории Башкирской АССР. Башкирские восстания в XVII и первой половине XVIII вв. М.-Л.: АН СССР, 1936. Ч. 1. 631 с.

Материалы..., 1949 - Материалы по истории Башкирской АССР. М.-Л.: АН СССР, 1949. Т. III. 691 с.

Материалы..., 2002 - Материалы по истории Башкортостана. Оренбургская экспедиция и

башкирские восстания 30-х годов XVIII в. Уфа: Китап, 2002. T. VI. 644 с.

НА РБ - Национальный архив Республики Башкортостан.

Нольде, 2013 - Нольде Б.Э. История формирования Российской империи. СПб.: Дмитрий Буланин, 2013. 637 c.

Полное собрание..., 1830 - Полное собрание законов Российской империи. Собр. 1. Т. IX. № 657.

СПб.: Типография II Отделения Собственной Его Императорского Величества Канцелярии, 1830. 1022 с. Путешествие..., 1939 - Путешествие Ибн-Фадлана на Волгу. М.-Л.: АН СССР, 1939. 124 с.

Рахимов, 2001 - Рахимов Р.Н. «Были в Москве... якобы от народу...»: Поездка башкирских и мишарского старшин в 1742 г. на коронацию императрицы Елизаветы I // Ядкяр. 2001. № 2. С. 34-43. 
РГАДА - Российский государственный архив древних актов.

Рычков, 2002 - Рычков П.И. История Оренбургская по учреждении Оренбургской комиссии. Уфа: Изд-во АН Республики Башкортостан, 2002. 195 с.

Соловьев, 1961 - Соловъев С.М. История России с древнейших времен. М.: Соцэкгиз, 1961. Кн. 6. T. 11-12. $682 \mathrm{c}$.

Таймасов, 2009 - Таймасов С.У. Башкирско-казахские отношения в XVIII в. М.: Наука, 2009. $317 \mathrm{c}$.

Татищев, 2005 - Татищев В.Н. История Российская. М.: Ермак, 2005. 578 с. $752 \mathrm{c}$.

Трепавлов, 2001 - Трепавлов В.В. История Ногайской Орды. М.: Восточная литература, 2001.

Трепавлов, 1997 - Трепавлов В.В. Ногаи в Башкирии, XV-XVII вв. Княжеские роды ногайского происхождения. Уфа: Урал. науч. центр РАН, 1997. 72 с.

Устюгов, 1947 - Устюгов Н.В. Башкирские восстание 1662-1664 гг. // Исторические записки. М.-Л.: Изд-во АН СССР, 1947. Т. 24. С. 30-110.

Фирсов, 1871 - Фирсов Н.Н. Инородческое население прежнего казанского царства в новой России до 1762 года и колонизация Закамских земель // Ученые записки Казанского университета. Казань, 1871. T. VI. С. 297-401.

Шмитт, 2016 - Шмитт К. Понятие политического. СПб.: Наука, 2016. 588 с.

Steinwedel, 2016 - Steinwedel Ch. Threads of Empire. Loyalty and Tsarist Authority in Bashkiria, 1552-1917. Bloomington: Indiana University Press, 2016. 398 p.

Tepeyurt, 2011 - Tepeyurt M. Bashkirs between Two Worlds, 1552-1824. Graduate Theses, Dissertations, and Problem Reports. West Virginia University. 2011. [Электронный ресурс] URL: https://core.ac.uk/download/pdf/ 230465305.pdf (дата обращения: 10.05.2021)

Tilly, 1997 - Tilly Ch. How empires end // After empire: multiethnic societies and nation-building. The Soviet Union, and the Russian, Ottoman and Habsburg empires / Barkey K., von Hagen M. (eds.). Boulder: Oxford: Westview press, 1997. Pp. 1-11.

\section{References}

Aznabaev, 2019 - Aznabaev, B.A. (2009). Apologiya plemennoi znati v «Defter-i-Chingizname» [The apology of the tribal nobility in "Defter-i-Chingiznam"]. Kazan. [in Russian]

Al'ternativnye puti..., 2000 - Al'ternativnye puti $\mathrm{k}$ tsivilizatsii (2000) [Alternative paths to civilization]. Moskva. [in Russian]

Bobrov, 2015 - Bobrov, L.A. (2015). Voennaya organizatsiya kazakhskikh kochevnikov ot Abulkhaira do Kenesary (XVIII - pervaya polovina XIX vv.) [Military organization of Kazakh nomads from Abulkhair to Kenesara (XVIII - first half of the XIX centuries)]. Moskva. [in Russian]

Bogoyavlenskii, 1939 - Bogoyavlenskii, S.K. (1939). Materialy po istorii kalmykov v pervoi polovine XVII v. [Materials on the history of the Kalmyks in the first half of the XVII century.]. Istoricheskie zapiski. 5: 48-101. [in Russian]

Bukanova, 1997 - Bukanova, R.G. (1997). Goroda-kreposti yugo-vostoka Rossii v XVIII v. Istoriya stanovleniya gorodov na territorii Bashkirii [Fortress cities of the south-east of Russia in the XVIII century. The history of the formation of cities on the territory of Bashkiria]. Ufa. [in Russian]

Georgi, 1799 - Georgi, I.G. (1799). Opisanie vsekh obitayushchikh v Rossiiskom gosudarstve narodov [Description of all the peoples living in the Russian state]. SPb. [in Russian]

Demidova, 2003 - Demidova, N.F. (2003). Bashkirskie posol'stva v Moskvu v XVII v. [Bashkir embassies to Moscow in the XVII century]. Moskva. [in Russian]

Dobrosmyslov, 1900 - Dobrosmyslov, A.I. (1900). Bashkirskii bunt v 1735, 1736 i 1737 gg. [Bashkir revolt in 1735, 1736 and 1737]. Orenburg. [in Russian]

Dokumenty..., 2012 - Dokumenty i materialy po istorii bashkirskogo naroda (1574-1798) (2012) [Documents and materials on the history of the Bashkir people (1574-1798)]. Ufa. [in Russian]

Dorofeev, 1994 - Dorofeev, V.V. (1994). Sakmarskii gorodok [Sakmarsky town]. Orenburg. [in Russian]

Istoriya..., 2011 - Istoriya bashkirskogo naroda (2011) [History of the Bashkir people]. Ufa.

[in Russian]

Istoriya..., 2005 - Istoriya Kazakhstana v russkikh istochnikakh (2005) [The history of Kazakhstan in

Russian sources]. Almaty. [in Russian]

Kappeler, 2000 - Kappeler, A. (2000). Rossiya - mnogonatsional'naya imperiya: Vozniknovenie.

Istoriya. Raspad [Russia - a multinational empire: The Emergence. History. Disintegration]. Moskva. [in Russian]

Koretskii, 1986 - Koretskii, V.I. (1986). Letopisets s novym izvestiem o vosstanii Bolotnikova

[Chronicler with new news about the Bolotnikov uprising]. Istoriya SSSR. 4: 62-77. [in Russian]

Korotaev, 2003 - Korotaev, A.V. (2003). Sotsial'naya evolyutsiya: faktory, zakonomernosti, tendentsii

[Social evolution: factors, patterns, trends]. Moskva. [in Russian] 
Materialy..., 1936 - Materialy po istorii Bashkirskoi ASSR. Bashkirskie vosstaniya v XVII i pervoi polovine XVIII vv. (1936). [Materials on the history of the Bashkir ASSR. Bashkir uprisings in the XVII and first half of the XVIII centuries]. Moskva-Leningrad. [in Russian]

Materialy..., 1949 - Materialy po istorii Bashkirskoi ASSR (1949) [Materials on the history of the Bashkir ASSR]. Moskva-Leningrad. [in Russian]

Materialy..., 2002 - Materialy po istorii Bashkortostana. Orenburgskaya ekspeditsiya i bashkirskie vosstaniya 30-kh godov XVIII v. (2002). [Materials on the history of Bashkortostan. The Orenburg expedition and the Bashkir uprisings of the 30 of of the XVIII century]. Ufa. [in Russian]

NA RB - Natsional'nyi arkhiv Respubliki Bashkortostan [National Archive of the Republic of Bashkortostan].

Nol'de, 2013 - Nol'de, B.E. (2013). Istoriya formirovaniya Rossijskoj imperii [History of the formation of the Russian Empire]. SPb. [in Russian]

Polnoe sobranie..., 1830 - Polnoe sobranie zakonov Rossiiskoi imperii (1830) [The complete collection of laws of the Russian Empire]. SPb. [in Russian]

Puteshestvie..., 1939 - Puteshestvie Ibn-Fadlana na Volgu (1939) [Ibn Fadlan's Journey to the Volga]. Moskva-Leningrad. [in Russian]

Rakhimov, 2001 - Rakhimov, R.N. (2001). «Byli v Moskve... yakoby ot narodu...»: Poezdka bashkirskikh i misharskogo starshin v $1742 \mathrm{~g}$. na koronatsiyu imperatritsy Elizavety I ["We were in Moscow ... allegedly from the people...": The trip of Bashkir and Mishar elders in 1742 to the coronation of Empress Elizabeth I]. Yadkyar. 2: 34-43. [in Russian]

RGADA - Rossijskij gosudarstvennyj arhiv drevnih aktov [Russian State Archive of Ancient Acts].

Rychkov, 2002 - Rychkov, P.I. (2002). Istoriya Orenburgskaya po uchrezhdenii Orenburgskoi komissii [Orenburg history on the establishment of the Orenburg Commission]. Ufa. [in Russian]

Solov'ev, 1961 - Solov'ev, S.M. (1961). Istoriya Rossii s drevneishikh vremen [The history of Russia since ancient times.]. Moskva. [in Russian]

Steinwedel, 2016 - Steinwedel, Ch. (2016). Threads of Empire. Loyalty and Tsarist Authority in Bashkiria, 1552-1917. Bloomington: Indiana University Press. 398 p.

Taimasov, 2009 - Taimasov, S.U. (2009). Bashkirsko-kazakhskie otnosheniya v XVIII v. [BashkirKazakh relations in the XVIII century]. Moskva. [in Russian]

Tatishchev, 2005 - Tatishchev, V.N. (2005). Istoriya Rossiiskaya [Russian History]. Moskva. [in Russian]

Tepeyurt, 2011 - Tepeyurt, M. (2011). Bashkirs between Two Worlds, 1552-1824. Graduate Theses, Dissertations, and Problem Reports. West Virginia University. [Electronic resource]. URL: https://core.ac.uk/ download/pdf/230465305.pdf (date of access: 10.05.2021).

Tilly, 1997 - Tilly, Ch. (1997). How empires end. After empire: multiethnic societies and nationbuilding. The Soviet Union, and the Russian, Ottoman and Habsburg empires. Barkey K., von Hagen M. (eds.). Boulder: Oxford: Westview press. Pp. 1-11.

Trepavlov, 2001 - Trepavlov, V.V. (2001). Istoriya Nogaiskoi Ordy [The history of the Nogai Horde]. Moskva. [in Russian]

Trepavlov, 1997 - Trepavlov, V.V. (1997). Nogai v Bashkirii, XV-XVII vv. Knyazheskie rody nogaiskogo proiskhozhdeniya [Nogai in Bashkiria, XV-XVII centuries. Princely families of Nogai origin]. Ufa. [in Russian]

Ustyugov, 1947 - Ustyugov, N.V. (1947). Bashkirskie vosstanie 1662-1664 gg. [The Bashkir Uprising of 1662-1664]. Istoricheskie zapiski. 24: 30-110. [in Russian]

Firsov, 1871 - Firsov, N.N. (1871). Inorodcheskoe naselenie prezhnego kazanskogo tsarstva v novoi Rossii do 1762 goda i kolonizatsiya Zakamskikh zemel' [The foreign population of the former Kazan Kingdom in the new Russia before 1762 and the colonization of the Zakamsky lands]. Uchenye zapiski Kazanskogo universiteta. VI: 297-401. [in Russian]

Shmitt, 2016 - Shmitt, K. (2016). Ponyatie politicheskogo [The concept of political]. SPb. [in Russian]

\section{Ликвидация договорного подданства башкир в 1725-1733 гг.}

Булат Ахмерович Азнабаев а, * , Алексей Иванович Кортунов b

а Башкирский государственный университет, Российская Федерация

b Башкирский государственный педагогический университет им. М. Акмуллы, Российская Федерация

\footnotetext{
${ }^{*}$ Корреспондирующий автор

Адреса электронной почты: azbulattt@rambler.ru (Б.А. Азнабаев), kortunov@rambler.ru (А.И. Кортунов)
} 
Аннотация. В литературе противоречивые трактовки российского подданства башкир XVIXVIII вв. вызваны утверждением о том, что башкиры не имели политической структуры, под которой понималась исключительно форма вождества или государства. Вместе с тем ряд исследователей в конце XX в. отметил, что политическое единство народа не всегда достигается путем образования жестких форм, отчуждающих суверенитет у общин. Башкирское общество середины XVI - первой трети XVIII вв. являет собой пример создания военной политии без привычной для кочевников властной вертикали. В середине XVI в. родоплеменные образования башкир объединились в горизонтальную структуру, которая в российских официальных документах XVIII в. получила название «Башкирская орда». Отсутствие в башкирском обществе институциональной элиты в лице чингизидов, обладающих правом на государственную власть, обусловило демократический характер башкирской политии. Все решения, связанные с политической экзистенцией (объявление войны или заключение мира), принимались на йыйынах - «мирских сходах» башкирских родов. Объединение башкирских родов в единую военную структуру было следствием соглашения с Российским государством, которое обязало башкир охранять южную границу своих земель. На юге башкирам противостояли кочевые вождества и государства (калмыки, ногаи, казахи, каракалпаки), в результате башкиры были вынуждены создать единую военную структуру, учитывающую их специфическое социальное устройство. Защита своей южной границы становится общим делом всего башкирского народа, поэтому наиболее ценные с хозяйственной точки зрения территории, находящиеся в приграничной полосе, стали собственностью всех башкирских родов.

Главное испытание военная полития башкир прошла в ходе массированного вторжения калмыков в 20-30-е гг. XVII в. Если прежние властители Башкирии - ногаи и сибирские шейбаниды - были вынуждены признать власть калмыков, то башкиры, даже утратив степные вотчины за Яиком, не только сумели отразить натиск превосходящего численно противника, но и перейти в наступление. В начале 1660-х гг. калмыцкие лидеры обуславливали принятие российского подданства прекращением набегов башкир и возвращением пленных. Однако в 1720-е гг. военная организация башкир впервые столкнулась с угрозой распада. Южные роды, потерявшие свои вотчины за Яиком вследствие продвижения на север казахов, поддержали намерение России построить город на границе Уфимской провинции. Однако основная часть башкир увидела в намерениях И.К. Кирилова стремление государства взять под своей контроль южную границу. Башкиры восприняли этот шаг властей как намерение расторгнуть соглашение о подданстве середины XVI в., гарантировавшее башкирам беспрецедентные привилегии в Российском государстве.

Ключевые слова: российское подданство башкир, Башкирская орда, южная граница Уфимского уезда, Оренбургская экспедиция. 